\title{
Grzegorz Grzybek, Etos życia. Wychowanie do matżeństwa w zaloże- niach etyki rozwoju, Wydawnictwo UR, Rzeszów 2014, ss. 176
}

DOI: http://dx.doi.org/10.12775/PCh.2014.036

Etos życia. Wychowanie do matzeństwa w założeniach etyki rozwoju to kolejna monografia naukowa autora teorii „etyki rozwoju”, dr. hab. Grzegorza Grzybka, prof. UR. Grzegorz Grzybek to etyk i pedagog oraz przedstawiciel rozwijającej się obecnie dyscypliny, jaką stanowią nauki o rodzinie. Jest Kierownikiem Zakładu Pedagogiki Opiekuńczej.

Najnowsza publikacja ma na celu wskazanie istotnych elementów wychowania do małżeństwa w odniesieniu do etosu życia. Autor w swojej pracy postawił następującą tezę: „kobieta i mężczyzna posiadają odmienne etosy życiowe, które w małżeństwie muszą się spotkać. Od jakości owego spotkania i jakości owych etosów zależy trwałość i szczęśliwość pożycia małżeńskiego. Wychowanie do małżeństwa powinno przede wszystkim obejmować właściwie ukształtowane etosy życiowe". Postawiona teza zakłada interdyscyplinarność ujęcia problemu naukowego, który powinien być rozwiązywany w odwołaniu do co najmniej trzech dyscyplin i subdyscyplin naukowych: pedagogiki, nauk o rodzinie, etyki.

Autor zaproponował dowiedzenie tezy poprzez analizę w pięciu ujęciach. Zostały one przedstawione w następujących rozdziałach: 1) Istota małżeństwa a płeć; 2) Kultura, małżeństwo, moralność; 3) Wychowanie do małżeństwa a założenia ,etyki rozwoju”; 4) Wartości i normy w małżeństwie a „etyka rozwoju”; 5) Etos życia a małżeństwo. Rozdziały są poprzedzone wstępem, który wyjaśnia koncepcję oraz przyjęte metody pracy. Te są uwarunkowane autorską teorią „etyki rozwoju”. Zakończenie (także w języku angielskim i słowackim) służy podsumowaniu i potwierdzeniu postawionej tezy. Autor obok bibliografii umieścił wykaz swoich publikacji, które potwierdzają szeroki obszar jego zainteresowań naukowych.

W pierwszym rozdziale autor przedstawił problem samotności i płci w kontekście małżeństwa, a także różnic między kobietą i mężczyzną. Rozdział ma zdecydowanie antropologiczny charakter i jest próbą ukazania istoty małżeństwa w odniesieniu do płci. Została tu także wypracowana własna definicja małżeństwa. Rozdział drugi to próba ukazania współczesnych przewartościowań dotyczących małżeństwa, w tym sporu o gender, i religijnego wymiaru małżeństwa. Autor przedstawia kwestię małżeństwa w kontekście kulturowym, religijnym i moralnym. Poprzez różne ujęcia stawia się w pozycji bezstronnego obserwatora. W kolejnym, trzecim rozdziale ukazuje pod- 
stawy wychowania do małżeństwa w odniesieniu do etosu życiowego. Podstawą rozważań czyni autorską teorię ,etyki rozwoju”. Podkreśla również konieczność wypracowania własnych standardów etycznych, poszukiwania nowego etosu, odpowiedniego do wyzwań, przed którymi staje człowiek. Tu także została wypracowana autorska definicja etosu życiowego. W rozdziale czwartym wskazuje na wartości i normy, stanowiące fundament więzi małżeńskiej, jak i osobowego rozwoju. Zostały tutaj omówione następujące wartości: miłość, szczęście, mądrość i wolność. Wybór do analizy takich wartości uzależniony był od koncepcji „etyki rozwoju”, ukazanej w pierwszej pracy tematycznej: Etyka rozwoju a wychowanie (Wyd. UR, Rzeszów 2010). W ostatnim rozdziale autor formułuje podstawy odpowiedzi na postawiony problem, wskazując, że o odmienności etosów męskiego i żeńskiego decydują emocje nadintelektualne. Rozważania w tym rozdziale dotyczą męskiego i żeńskiego etosu; męstwa i czułości jako charakterystyk powyższych etosów, a także wychowania pojętego jako formacja w odniesieniu do rozwoju etosu życiowego. Wskazując na pozytywny wymiar stereotypów, postuluje rozwijanie męskości przez mężczyzn i czułości przez kobiety. Natomiast o jakości wychowania do małżeństwa, jego zdaniem, decyduje całożyciowa formacja potwierdzona w życiowym etosie.

Autor wykazał się świeżością refleksji i niezależnością stawianych sądów, potwierdzoną ukształtowaną i doprecyzowaną teorią naukową, pozwalającą na analizę różnych problemów wychowawczych i społecznych. Jak sam autor pisał we wprowadzeniu, każde dookreślenie będące istotą dyskursu naukowego będzie powodowało, że powstała w wyniku refleksji naukowej prawda w pewnym sensie ,zaszufladkuje” rzeczywistość. Bo będzie to rzeczywistość widziana oczami naukowca, a nie rzeczywistość sama w sobie. Jednak sądzę, że dzięki temu definiowaniu możemy lepiej ją poznać, a tym samym zrozumieć. W książce tej zawarta jest taka próba spojrzenia, która, jak wspomniałam, choć „szufladkuje”, to jednak pozwala nazwać istotę i sens wychowania do małżeństwa.

Poszczególne tezy mogą być kontrowersyjne, jak na przykład, że o różnicach etosu kobiecego i męskiego decyduje odmienność przeżywania, ukazywana w koncepcji emocji nadintelektualnych (idea zaczerpnięta z poglądów Henryka Bergsona). Autor także od strony metodologicznej przyjął stanowisko niezależne od tradycyjnego, diagnostycznego ujęcia przeważającego w pracach pedagogicznych. Wskazując na interdyscyplinarny wymiar refleksji, w którym metodologia z obszaru nauk humanistycznych stanowi podstawę refleksji, należy oczekiwać intersubiektywności ujęcia. Wydaje się, że to właśnie się udało, ponieważ koncepcja jest spójna i prowadzi do 
własnych wniosków, do których mogą przekonać się inni. Książka stanowi lekturę wartą polecenia i wydaje się cenną nowością na rynku wydawniczym.

Agnieszka Bielak*

* Mgr Agnieszka Bielak, absolwentka pedagogiki Uniwersytetu Rzeszowskiego, doktorantka Uniwersytetu Preszowskiego, Wydział Filozoficzny, Instytut Etyki i Bioetyki. 